\title{
Relation Between Hormonal Contraception with Menopause
}

\author{
Santi Susanti,Hariyani Sulistyoningsih \\ STIKes Respati \\ santiazhari@gmail.com, hariyani5677@gmail.com
}

\begin{abstract}
Menopause is a process of transition from a productive period heading slowly to the non-productive time due to reduced estrogen and progesterone. There are many factors associated with menopause. Factors contraceptives may affect the occurrence of menopause, which in women who use hormonal contraception to have compromised menopause compared to those using a non-hormonal contraception. The purpose of this study was to determine the relationship between hormonal contraception and menopause. The research method uses a Systematic Literature Review. The independent variable is hormonal contraception. The dependent variable is Menopause Age. The population is all research journals with the topic of the relationship between hormonal contraception and age menopause. The sample is a journal of research results of the relationship between hormonal contraception and age menopause. Sample inclusion criteria in this study include: 1). Subjects of the study were postmenopausal women, 2). The type of research is case control and cross sectional 4). National and international journals of the10 years last. The results of the study found that hormonal contraception was associated with age at menopause. Suggestions for women postmenopausal to have a healthy lifestyle and have regular the health check to health care facilities.
\end{abstract}

Keywords: contraception, hormonal, menopause

\section{BACKGROUND}

Menopause is a process of transition from a productive period heading slowly to the non-productive time due to reduced estrogen and progesterone. Menopause is the process of stopping the physiology of the menstrual cycle associated with the elderly. At the age of 40 years and over, about $80 \%$ of women begin to have irregular menstrual cycles. Only about $10 \%$ of women stop menstruating altogether without prolonged cycle irregularities. Before menopause, the main estrogen the body produces is estradiol. During perimenopause a woman begins to produce more estrogen of a different type called estrone which is produced in the ovaries as well as in body fat (1). Early menopause estrogen production does not stop suddenly. This is because there is no damage to the walls of the ovaries, only the production is gradually less. A drastic decrease in the levels of the hormone's estrogen and progesterone in some women will affect various physical changes and very individual psychological conditions including wrinkled or skin sagging, incontinence or urinary disorders control, heart palpitations, increased body temperature, headaches and forgetfulness. While changes in psychological conditions often cause feelings of depression, depression and irritability (1).

There are many factors associated with menopause. Research by Rosyanda, et al (2016) found a relationship between parity and age of menarche with menopause. The more often a woman gives birth, the older or longer the woman enters menopause (2). This is because pregnancy and childbirth will slow down the work system of the female reproductive organs and can also slow down the aging of the body. Likewise, research by Rangki et al (2020) found history of contraceptive use, BMI, age, parity was related to age at menopause. Contraceptive factors can affect the occurrence of menopause, where mothers who use contraception hormonal will experience menopause delays compared to those who use non-hormonal contraception (3). 
According to the BKKBN, active family planning among PUS in 2019 was 62.5\%, a decrease from the previous year, which was $63.27 \%$. While the RPJMN target to be achieved in 2019 is $66 \%$. The results of the 2017 IDHS also show a higher number for active family planning, which is $63.6 \%$. The highest active family planning was in Bengkulu at $71.4 \%$ and the lowest was in West Papua at $25.4 \%$. There are 11 (eleven) provinces with active family planning coverage reaching the RPJMN target of $66 \%$, namely Bengkulu, South Kalimantan, Lampung, Jambi, Bangka Belitung Islands, Bali, West Java, Central Kalimantan, South Sumatra, North Sulawesi and Gorontalo. Based on the pattern in choosing the type of contraception, most of the active family planning participants chose injections and pills as contraceptives and were even very dominant (more than $80 \%$ ) compared to other methods; injections (63.7\%) and pills (17.0\%) (4).

Based on this, it is necessary to study the evidence to examine the relationship between the use of hormonal contraception and the age of menopause. Therefore, the author intends to examine several research results through the method literature review with the formulation of the problem whether there is a relationship between the use of hormonal contraception and the age of menopause?

\section{METHOD}

This research method uses a Systematic Literature Review, researchers analyze the relationship between hormonal contraceptive use and menopause age. The independent variable is hormonal contraception. The dependent variable is Menopause Age. The population is all research journals with the topic of the relationship between hormonal contraception and age menopause. The sample is a journal of research results of the relationship between hormonal contraception andage menopause. Sample inclusion criteria in this study include: 1). Subjects of the study were postmenopausal women, 2). The type of research is case control and cross sectional 4). National and international journals of the 10 years last.
The strategy of searching for research articles is national and journals international that are relevant to the research topic and using the keywords: "contraceptives hormonal", "Menopause", to databases namely Pubmed, The Lancet, Google scholars, with a time limit of January 2010 to December 2020. Full-text articles were reviewed to select research journals that matched the sample inclusion criteria.

Based on the results of the assessment, 5 journals were obtained from 21 selected journals using the Duffy's Research Appraisal Checklist Approach, 5 research journals that were categorized as eligible to be used as samples in this study for further analysis, Critical Review of Systematic Review Articles and Meta-Analysis, including validity, results, and its relevance. Aspects that are criticized include: year of publication, design, sampling, variables, data analysis, instruments, research results, and conclusions.

\section{RESULT}

The results of the review of the authors found 5 literatures related to hormonal contraception on age menopausal. The results of the analysis of the literature can be seen in table 1.1 below: 
Journal Of Ageing And Family (JOAF)

Edition 1, No 1, October 2021

Table 1. Analysis of the Relationship between the Use of Hormonal Contraception to Menopause Age

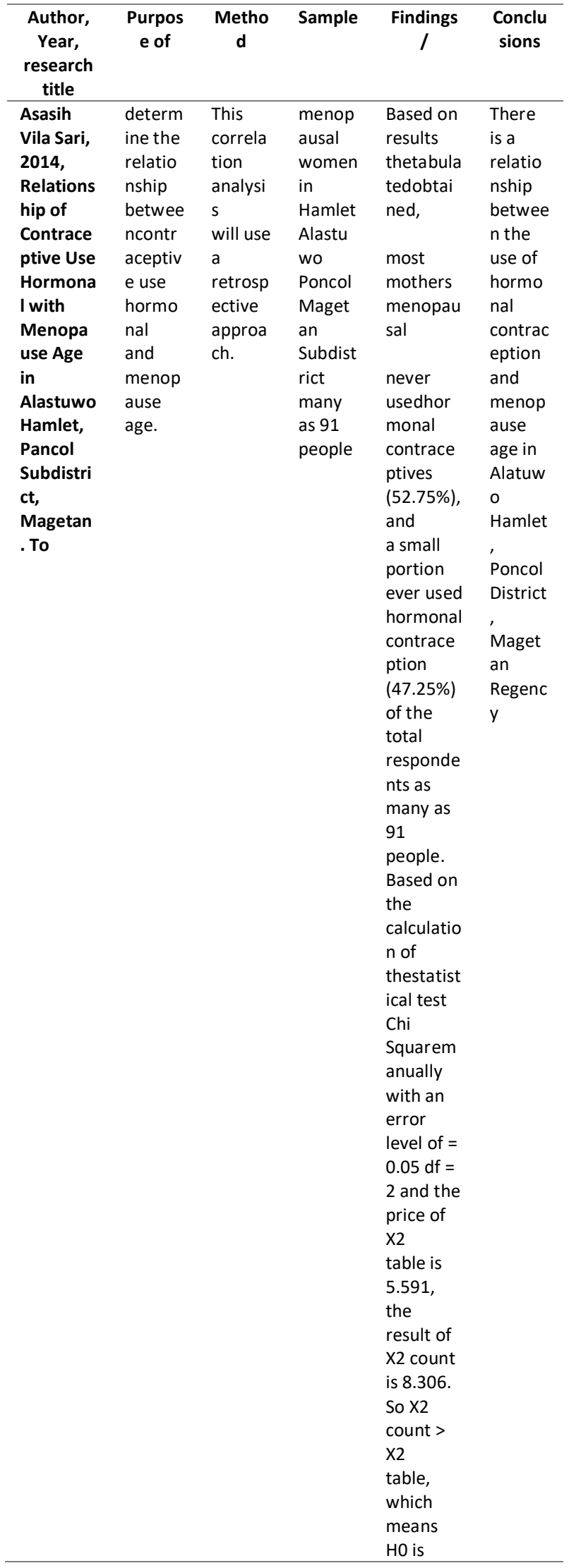

\begin{tabular}{|c|c|c|c|c|c|}
\hline & & & & $\begin{array}{l}\text { rejected } \\
\text { and } \mathrm{H} 1 \text { is } \\
\text { accepted, } \\
\text { meaning } \\
\text { that } \\
\text { there is a } \\
\text { relations } \\
\text { hip } \\
\text { between } \\
\text { the use } \\
\text { of } \\
\text { hormonal } \\
\text { contrace } \\
\text { ption and } \\
\text { the age } \\
\text { of } \\
\text { menopau } \\
\text { se. KK = } \\
0.657 \\
\text { indicates } \\
\text { a close } \\
\text { relations } \\
\text { hip in the } \\
\text { level of }\end{array}$ & \\
\hline $\begin{array}{l}\text { Nabila } \\
\text { Wahid, } \\
\text { 2016, } \\
\text { The } \\
\text { Relations } \\
\text { hip } \\
\text { between } \\
\text { Contrace } \\
\text { ptive Use } \\
\text { and } \\
\text { Menopa } \\
\text { use } \\
\text { Incidence } \\
\text { in } \\
\text { Mothers } \\
\text { At Lau } \\
\text { Maros } \\
\text { Public } \\
\text { Health } \\
\text { Center }\end{array}$ & $\begin{array}{l}\text { Knowin } \\
\text { g the } \\
\text { Relatio } \\
\text { nship } \\
\text { betwee } \\
\mathrm{n} \\
\text { Contra } \\
\text { ceptive } \\
\text { Use } \\
\text { and } \\
\text { Menop } \\
\text { ause } \\
\text { Inciden } \\
\text { ce In } \\
\text { mother } \\
\text { At the } \\
\text { Lau } \\
\text { Maros } \\
\text { Public } \\
\text { Health } \\
\text { Center }\end{array}$ & $\begin{array}{l}\text { analyti } \\
\text { cal } \\
\text { observ } \\
\text { ation } \\
\text { with } \\
\text { cross } \\
\text { section } \\
\text { al } \\
\text { metho } \\
\text { d. }\end{array}$ & 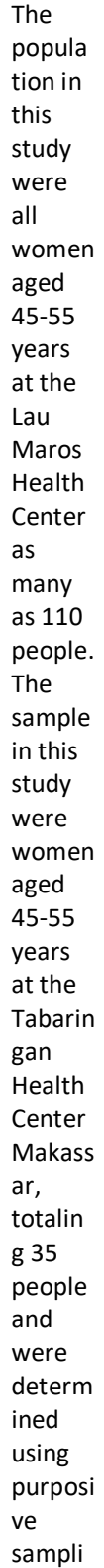 & $\begin{array}{l}\text {,who } \\
\text { used } \\
\text { injectabl } \\
\text { e } \\
\text { contrace } \\
\text { ption, } \\
\text { there } \\
\text { were } 8 \\
\text { responde } \\
\text { nts } \\
\text { (23\%)whi } \\
\text { le } 27 \\
\text { responde } \\
\text { nts } \\
\text { (77\%). } \\
\text { Respond } \\
\text { ents } \\
\text { who used } \\
\text { pill } \\
\text { contrace } \\
\text { ption } \\
\text { were } \\
\text { found } \\
\text { to be } 17 \\
\text { responde } \\
\text { nts } \\
\text { (48.6\%) } \\
\text { while } \\
\text { those } \\
\text { who did } \\
\text { not use } \\
\text { were } \\
\text { found to } \\
\text { be } 18 \\
\text { responde } \\
\text { nts } \\
\text { (51.4\%). } \\
\text { The test } \\
\text { used was } \\
\text { Fisher's } \\
\text { test with } \\
\text { a } \\
\text { significan } \\
\text { ce value } \\
\text { (0.05), } \\
\text { then }\end{array}$ & 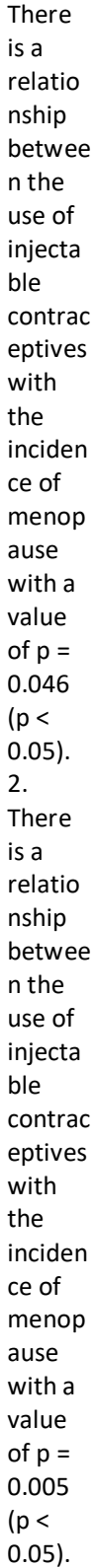 \\
\hline
\end{tabular}




\begin{tabular}{|c|c|c|c|c|c|c|c|c|c|c|c|}
\hline & & & $\begin{array}{l}\text { ng, } \\
\text { which } \\
\text { is a } \\
\text { way of } \\
\text { taking } \\
\text { sample } \\
\text { s from } \\
\text { among } \\
\text { the } \\
\text { popula } \\
\text { tion by } \\
\text { selecti } \\
\text { ng the } \\
\text { sample } \\
\text { desired } \\
\text { by the } \\
\text { researc } \\
\text { her so } \\
\text { that } \\
\text { the } \\
\text { sample } \\
\text { can } \\
\text { repres } \\
\text { ent the } \\
\text { charact } \\
\text { eristics } \\
\text { of the } \\
\text { popula } \\
\text { tion } \\
\text { that } \\
\text { have } \\
\text { been } \\
\text { known. } \\
\text { Previo } \\
\text { usly }\end{array}$ & 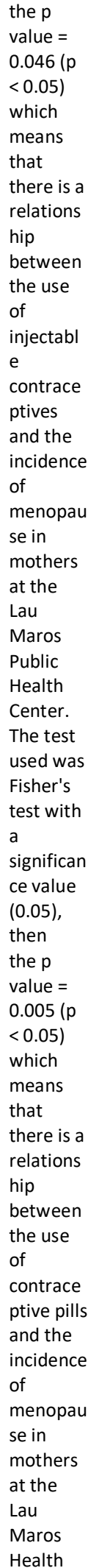 & & (⿸丆口 & $\begin{array}{l}\text { and } \\
\text { use of } \\
\text { hormo } \\
\text { nal KB } \\
\text { with } \\
\text { Menop } \\
\text { ausal } \\
\text { Age }\end{array}$ & $\begin{array}{l}\text { survey } \\
\text { using a } \\
\text { cross } \\
\text { section } \\
\text { al } \\
\text { approa } \\
\text { ch. } \\
\text { Resear } \\
\text { ch }\end{array}$ & $\begin{array}{l}\text { postme } \\
\text { nopaus } \\
\text { al } \\
\text { women } \\
\text { in the } \\
\text { Elderly } \\
\text { Posyan } \\
\text { du } \\
\text { ' Tingkir } \\
\text { Village, } \\
\text { Salatig } \\
\text { a in } \\
\text { April } \\
\text { 2014 } \\
\text { with a } \\
\text { total of } \\
\text { 58 } \\
\text { respon } \\
\text { dents. } \\
\text { The } \\
\text { sample } \\
\text { in this } \\
\text { study } \\
\text { were } \\
\text { postme } \\
\text { nopaus } \\
\text { al } \\
\text { women } \\
\text { at the } \\
\text { Elderly } \\
\text { dents. } \\
\text { Posyan } \\
\text { du, } \\
\text { Tingkir } \\
\text { Village, } \\
\text { Salatig } \\
\text { a, in } \\
\text { April } \\
\text { tolu a } \\
\text { ron }\end{array}$ & 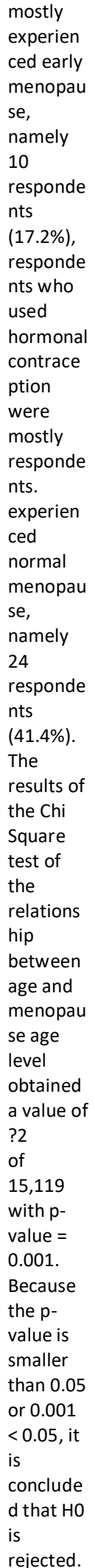 & $\begin{array}{l}\text { hormo } \\
\text { nal } \\
\text { family } \\
\text { plannin } \\
\text { g and } \\
\text { the age } \\
\text { of } \\
\text { menop } \\
\text { ause in } \\
\text { mother } \\
\text { s at the } \\
\text { Elderly } \\
\text { Posyan } \\
\text { du, } \\
\text { Tingkir } \\
\text { Village, } \\
\text { Salatig } \\
\text { a, with } \\
\text { a p } \\
\text { value } \\
\text { of } \\
0.001 .\end{array}$ \\
\hline $\begin{array}{l}\text { Mayang } \\
\text { Isa } \\
\text { Hanasiwi } \\
\text {, Herdini } \\
\text { Widyani } \\
\text { ng } \\
\text { Pertiwi, }\end{array}$ & $\begin{array}{l}\text { Knowin } \\
\text { g the } \\
\text { relatio } \\
\text { nship } \\
\text { betwee } \\
\mathrm{n} \\
\text { parity }\end{array}$ & $\begin{array}{l}\text { This } \\
\text { study } \\
\text { is } \\
\text { anrese } \\
\text { arch } \\
\text { analyti } \\
\text { cal }\end{array}$ & $\begin{array}{l}\text { The } \\
\text { popula } \\
\text { tion in } \\
\text { this } \\
\text { study } \\
\text { were } \\
\text { all }\end{array}$ & $\begin{array}{l}\text { Center. } \\
\text { Respond } \\
\text { ents who } \\
\text { did not } \\
\text { use } \\
\text { hormonal } \\
\text { contrace } \\
\text { ption }\end{array}$ & $\begin{array}{l}\text { There } \\
\text { is a } \\
\text { relatio } \\
\text { nship } \\
\text { betwee } \\
n \text { the } \\
\text { use of }\end{array}$ & $\begin{array}{l}\text { Endang } \\
\text { Buda } \\
\text { Setyowat } \\
\text { i, 2017, } \\
\text { The } \\
\text { Effect of } \\
\text { Hormona } \\
\text { I }\end{array}$ & $\begin{array}{l}\text { Knowin } \\
\mathrm{g} \text { the } \\
\text { Effect } \\
\text { of } \\
\text { Hormo } \\
\text { nal } \\
\text { Contra } \\
\text { ception }\end{array}$ & $\begin{array}{l}\text { Cross } \\
\text { section } \\
\text { al } \\
\text { survey } \\
\text { study }\end{array}$ & $\begin{array}{l}\text { The } \\
\text { popula } \\
\text { tion in } \\
\text { this } \\
\text { study } \\
\text { were } \\
\text { all } \\
\text { elderly }\end{array}$ & $\begin{array}{l}\text { mothers } \\
\text { elderlyw } \\
\text { ho used } \\
\text { non- } \\
\text { hormonal } \\
\text { contrace } \\
\text { ption the } \\
\text { majority }\end{array}$ & $\begin{array}{l}\text { Based } \\
\text { on the } \\
\text { results } \\
\text { it can } \\
\text { be } \\
\text { conclu } \\
\text { ded } \\
\text { that }\end{array}$ \\
\hline
\end{tabular}


Journal Of Ageing And Family (JOAF)

Edition 1, No 1, October 2021

\begin{tabular}{|c|c|c|c|c|}
\hline $\begin{array}{l}\text { Contrace } \\
\text { ption } \\
\text { Use With } \\
\text { Menopa } \\
\text { use Age }\end{array}$ & $\begin{array}{l}\text { Use } \\
\text { With } \\
\text { Menop } \\
\text { ause } \\
\text { Age }\end{array}$ & $\begin{array}{l}\text { women } \\
\text { at the } \\
\text { Posyan } \\
\text { du } \\
\text { elderly } \\
\text { BPS } \\
\text { Kiswor } \\
\text { o } \\
\text { Pratiwi } \\
\text { in the } \\
\text { period } \\
\text { May- } \\
\text { June } \\
2017 \\
\text { of } 80 \\
\text { people. } \\
\text { The } \\
\text { sample } \\
\text { in this } \\
\text { study } \\
\text { were } \\
\text { some } \\
\text { of the } \\
\text { elderly } \\
\text { techniq } \\
\text { ues } \\
\text { at BPS } \\
\text { Kiswor } \\
\text { o by } 45 \\
\text { people } \\
\text { with } \\
\text { probab } \\
\text { ility } \\
\text { samplic } \\
\text { ng } \\
\text { techniq } \\
\text { ue } \\
\text { sampli } \\
\text { ng with } \\
\text { atic } \\
\text { ando } \\
\text { and }\end{array}$ & 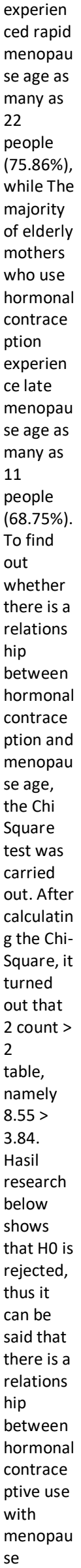 & $\begin{array}{l}\text { There } \\
\text { is a link } \\
\text { betwee } \\
n \\
\text { hormo } \\
\text { nal } \\
\text { contrac } \\
\text { eption } \\
\text { with } \\
\text { menop } \\
\text { ause. } \\
\text { Sugges } \\
\text { tion }\end{array}$ \\
\hline
\end{tabular}

\begin{tabular}{|c|c|c|c|c|c|}
\hline $\begin{array}{l}\text { Ayu } \\
\text { Wahyuni } \\
\text {, 2019, } \\
\text { The } \\
\text { Relations } \\
\text { hip } \\
\text { between } \\
\text { Hormona } \\
\text { I } \\
\text { Contrace } \\
\text { ption } \\
\text { Use With } \\
\text { Menopa } \\
\text { use Age } \\
\text { in } \\
\text { Lalongga } \\
\text { sumeeto } \\
\text { District, } \\
\text { Konawe } \\
\text { Regency } \\
\text { in } 2019\end{array}$ & $\begin{array}{l}\text { Knowin } \\
\text { g the } \\
\text { Relatio } \\
\text { nship } \\
\text { betwee } \\
n \\
\text { Hormo } \\
\text { nal } \\
\text { Contra } \\
\text { ception } \\
\text { Use } \\
\text { with } \\
\text { Menop } \\
\text { ause } \\
\text { Age in } \\
\text { Lalong } \\
\text { gasum } \\
\text { eeto } \\
\text { District } \\
\text { ' } \\
\text { Konaw } \\
\text { e } \\
\text { Regenc } \\
\text { y in } \\
2019\end{array}$ & $\begin{array}{l}\text { This } \\
\text { study } \\
\text { used a } \\
\text { cross } \\
\text { section } \\
\text { al } \\
\text { approa } \\
\text { ch. }\end{array}$ & 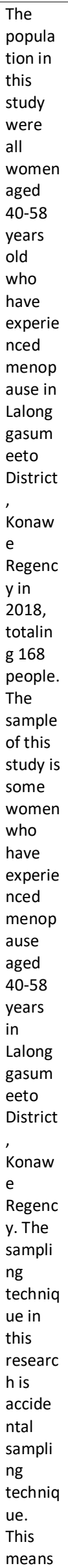 & 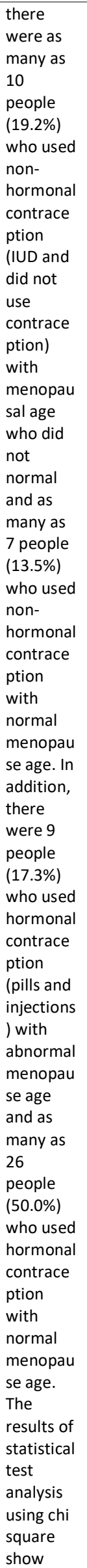 & $\begin{array}{l}\text { there is } \\
\text { a } \\
\text { relatio } \\
\text { nship } \\
\text { betwee } \\
\text { n the } \\
\text { use of } \\
\text { hormo } \\
\text { nal } \\
\text { contrac } \\
\text { eption } \\
\text { and } \\
\text { menop } \\
\text { ause } \\
\text { age in } \\
\text { Lalong } \\
\text { gasum } \\
\text { eeto } \\
\text { District } \\
\text { Konaw } \\
\text { e } \\
\text { Regenc } \\
\text { y in } \\
2019 \text { at } \\
\text { a } 95 \% \\
\text { confide } \\
\text { nce } \\
\text { level ( } \alpha \\
=0.05 \text { ). }\end{array}$ \\
\hline
\end{tabular}




\begin{tabular}{lll}
\hline that & that \\
the & value $=$ \\
sample & $0.020<=$ \\
taken & 0.05 then \\
is & Ha is \\
women & accepted. \\
who & This \\
have & means \\
experie & that \\
nced & there is a \\
menop & relations \\
ause & hip \\
who & between \\
were & the use \\
met at & of \\
the & hormonal \\
&
\end{tabular}

Menopause is the last uterine bleeding that is still regulated by the function of ovarian hormones. Hormones are chemical compounds carried by the blood to various parts of the body to perform certain functions. There is one group of hormones called hormones sexor steroid hormones. Included in this group are the hormones estrogen, progesterone and androgen (testosterone). Female sex hormones produced in the ovaries and adrenal glands carry female characteristics, affect the body's biology, and also play an important role in puberty until menopause. At the beginning of menopause estrogen production will not stop suddenly. This is becauseno there isdamage to the ovaries, only the production is gradually decreasing (1)

Sari's research (2014) on 91 respondents, shows that most of the respondents have never used hormonal contraception as much as $52.75 \%$ and a small proportion of respondents have never used hormonal contraception. use hormonal contraception as much as $47.25 \%$. While most of the respondents' menopause age is $51-55$ years as much as $40.66 \%$ and a small proportion of respondents' menopause age is 46-50 years as much as $29.67 \%$. These results were then tested with Chi Square statistical test with alevel significanceof $5 \%$ and degrees of freedom 2 obtained $X 2$ count 8.306 and $X 2$ table 5.591. $X 2$ count $>$ $X$ table so that $\mathrm{Ho}$ is rejected and $\mathrm{H} 1$ is accepted. The conclusion of this study is that there is a relationship between the use of hormonal contraception and the

$\begin{array}{ll}\text { study } & \text { contrace } \\ \text { site } & \text { ption and } \\ \text { when } & \text { menopau } \\ \text { the } & \text { se age in } \\ \text { researc } & \text { Lalongga } \\ \text { hers } & \text { sumeeto } \\ \text { visited } & \text { District, } \\ \text { the } & \text { Konawe } \\ \text { place } & \text { Regency } \\ & \text { in 2019 } \\ & \text { at a 95\% } \\ & \text { confiden } \\ & \text { ce level } \\ & (\alpha= \\ & 0.05) .\end{array}$

age of menopause. Women who use hormonal contraceptives will take longer or older to enter menopause, this is due to the way contraception works that suppress the work of the ovaries or ovaries (5). Any sex hormone can suppress the production of gonadotropins in the pituitary gland (especially those intended for contraception, namely folliclestimulating hormone / FSH and luteinizing hormone / LH. This suppression of hormone production occurs when sex hormones produce negative feedback on the hypothalamus, which then inhibits the secretion of releasing factors. hypothalamus, which in turn suppresses FSH and LH (5).

Wahid in his research in 2016 also found that there was a relationship between the use of injectable contraception and the incidence of menopause in mothers at the Lau Maros Health Center. The test used was Fisher's exact test with a significance value (0.05), then the $p$ value $=0.005(p<0.05)$ which means that there is a relationship between the use of oral contraceptives and the incidence of menopause in mothers at the Lau Maros Public Health Center.The results showed that of the 35 respondents who were assessed on the use of injectable contraceptives, 8 were found. Mothers (23\%) who use injectable contraception and all mothers who use contrast injection injection 5 or more than 5 years late to menopause. This condition can be influenced by hormones contained in injectable contraceptives that prevent the release of eggs released by women, 
without the release of eggs a woman is not likely to get pregnant. In addition, with the use of depo provera, the endometrium becomes thinner with reduced glandular activity, with the hormone progestin slightly stimulating the onset of menstruation every month, so it can be seen that most respondents who use injectable contraceptives aged over 45 years are still menstruating, while from 27 mothers ( $77 \%$ ) who did not use injectable contraception found 10 mothers who went through menopause quickly with several complaints such as insomnia and fatigue. In addition to not using hormonal contraception as previously described, the incidence of rapid menopause is usually also influenced by workload and the number of children or the number of times a woman gives birth. From the results of the study, it was also found that complaints of mothers who use injectable contraception about erratic bleeding and irregular menstruation, where the intervals can be lengthened or shortened and this is one of the symptoms of menopause (6). The same thing was also found in the research of Mayang Isa et al. They found that respondents who did not use hormonal contraception mostly experienced early menopause, namely 10 respondents $(17.2 \%)$, respondents who used hormonal contraception, most respondents experienced normal menopause, namely 24 respondents (41.4\%). ) (7).

The age of menopause in women will cause a decrease in the number of primordial follicles that occurs continuously, until at the age of about 50 years, ovarian function becomes very decreased. Follicles that reach a critical number will cause disruption of the hormone regulation system which results in corpus luteum insufficiency, anovulatory menstrual cycles and ultimately oligomenorrhea and amenorrhea. At the age of menopause women will enter a climacteric period which causes decreased levels of the hormones estrogen and progesterone, so that at that age women will feel climacteric symptoms. Most women begin to experience climacteric symptoms at the age of 40 years in the period premenopause and the peak is reached at the age of 50 years, namely menopause. This condition is in line with Wahyuni's research (2019) which also found a relationship between the use of hormonal contraception and menopause age in Lalonggasumeeto District, Konawe Regency. His research showed that most of the respondents had normal menopause age (age $40-58$ years) as many as 33 people (63.5\%). The age of menopause in women can occur at the age of 40-58 years but in certain circumstances it can occur earlier or later. Menopause is a normal life event which is marked by the physiological cessation of the last menstrual period which is associated with a woman's advanced age. Menopause is a natural process that must be accepted as a path of human life, carrying out activities such as exercise regular, consuming foods that contain lots of vitamins and calcium, reducing consumption of tea, fat, soda and alcohol, avoiding smoking, using foods that contain isoflavones such as soybeans, tofu, tempeh and soy sauce. Perform routine gynecological, laboratory (blood sugar and cholesterol) examinations, Pap smears and breast palpation (9)

\section{CONCLUSION}

Hormonal contraceptives are associated with age at menopause. Suggestions for women premenopausal to have a healthy lifestyle and have regular the health checks posyandu or to health care facilities. 


\section{BIBLIOGRAPHY}

1. Lestary D. Ins and outs of Menopause. Ali Z, editor. Jogjakarta: Your Gerail; 2010. 13-18 p.

2. Rosyada, Mujahidah Amrina; Fatima SR. Factors Associated with Menopausal Age. J Masy Health [Internet]. 2013;4(m):10-2. Available from: http://ejournals1.undip.ac.id/index.php/jkm\%0A

3. Rangki L, Ode Alifariki L, Siagian JOURNAL OF COMMUNITY HEALTH HJ, Alpukat J, Pelangi Residence No $P$, Kendari K, et al. Analysis Of Factors Related To Menopause Age At WuaWua Health Care Center, Kendari City Analysis of Factors Related to Menopause Age at Wua-Wua Health Center Kendari City. JournalHtpAcld [Internet]. 2020;6(3):348-54. Available from: http://jurnal.htp.ac.id

4. Kusumaryani M. Brief notes : Prioritize adolescent reproductive health to enjoy the demographic bonus. Lemb Demogr FEB UI [Internet]. 2017;1-6. Available from: http://ldfebui.org/wpcontent/uploads/2017/08/BN-062017.pdf
5. Sari A, Lestari D. The Relationship between Use of Hormonal Contraception and Menopause Age in Alastuwo Hamlet, Poncol Magetan. J Chem Inf Model. 2013;53(9):1-10.

6. Wahid N. The Relationship between Contraceptive Use andIncidence Menopause in Mothers at the Lau Maros Public Health Center. J Vocational Midwifery. 2020;61-6.

7. Isa Hanasiwi Mayang HWP. Journal of Midwifery RELATIONSHIP PARITY AND USE OF HORMONAL KB WITH. 2015;VII(02):208-22.

8. Sari DP, Sawitri E, Putri ZE. The Relationship of Long Use of Hormonal Contraception with Climacteric Symptoms in Menopausal Age Women in Gumul Village. J Holist Nursci. 2021;8(1):39-45.

9. Wahyuni A. The Relationship between Hormonal Contraceptive Use and Menopause Age in Lalonggasumeeto District, Konawe Regency in 2019. 2019; 